\title{
An Evaluation for the Anxiety and Depression Levels of Emergency
}

\section{Medicine Professionals}

\author{
Acil Serviste Çalışanların Anksiyete ve Depresyon Düzeylerinin Değerlendirilmesi
}

\author{
Ahmet Tugrul Zeytin ${ }^{1}$, Şeyhmus Kaya ${ }^{2}$, Davut Kaplan ${ }^{3}$, Aslı Melek Zeytin ${ }^{4}$, Filiz Baloğlu Kaya ${ }^{5}$ \\ ${ }^{1}$ Bilecik Provincial Health Directorate, Bilecik, Turkey \\ ${ }^{2}$ Eskişehir City Hospital, Department of Emergency Medicine, Eskişehir, Turkey \\ ${ }^{3}$ Eskişehir Yunus Emre State Hospital, Department of Emergency Medicine, Eskişehir, Turkey \\ ${ }^{4}$ Eskişehir Provincial Health Directorate, Eskişehir, Turkey \\ ${ }^{5}$ Osmangazi University, Department of Emergency Medicine, Eskişehir, Turkey
}

\begin{abstract}
Introduction: Psychological problems occur higher among medical staff than the other members of society. Emergency medicine is a highly difficult branch both physically and emotionally. In this study, it is aimed to identify anxiety and depression levels and related factors of emergency medicine professionals.

Methods: Eskisehir State Hospital and Eskisehir Yunus Emre State Hospital emergency medicine professionals and, health professionals who had previously work in the emergency department but continued to work in a unit other than the emergency department for the past year were also included in this study as a comparison group. Data collection was carried out with a form containing demographic information, Beck Anxiety Inventory and Beck Depression Inventory.

Results: Health professionals took part in this study as 75 cases and 75 comparison groups. When emergency medicine professionals were examined in terms of working conditions(physical conditions and working hours), depression levels found to be higher in those who were not satisfied with their working conditions $(p=0,024)$. In case and comparison groups, the anxiety levels of participants who have been subjected to verbal or physical violence has been determined higher than the participants who have not been subjected to verbal or physical violence (case group $p=0,006$, comparison group $p=0,003$ ).

Conclusion: A mild level of anxiety and depression is observed in emergency medicine professionals. However, verbal and physical violence and working conditions were observed to be the most effective factors on anxiety and depression. It is necessary to regulate working conditions for emergency medicine professionals and to plan preventive studies for verbal and physical violence.
\end{abstract}

Key words: Emergency, anxiety, depression.

\section{INTRODUCTION}

Emergency medicine is a highly difficult branch both physically and emotionally (1). Deformity can cause physical and emotional problems for people who are

\section{ÖZET}

Giriş: Sağlık çalışanlarında psikolojik sıkıntılar toplumun diğer bireylerine göre daha sık görülmektedir. Acil tıp fiziksel ve duygusal olarak zorlu bir tıp branşıdır. Bu çalışmada acil servis profesyonellerinin anksiyete ve depresyon düzeyleri ve ilişkili faktörlerin tanımlanması amaçlanmıştır.

Yöntemler: Eskişehir Devlet Hastanesi ve Eskişehir Yunus Emre Devlet Hastanesi acil servislerinde çalışan sağlık profesyonelleri ile önceden acil serviste çalışmış ancak son bir yıldır acil servis dışında başka bir birimde çalışmaya devam eden sağlık profesyonelleri de karşılaştırma grubu olarak çalışmaya dahil edilmişdir. Demografik bilgiler, Beck Anksiyete Ölçeği ve Beck Depresyon Ölçeğini içeren form ile veri toplaması gerçekleştirilmiştir.

Bulgular: Sağlık profesyonelleri 75 kişilik vaka ve 75 kişilik karşılaştırma grubu olarak çalışmada yer almıştır. Acil servis çalışanları çalışma şartları (fiziksel şartlar ve çalışma saatleri) açısından incelendiğinde, depresyon düzeyleri çalışma şartlarından memnun olmayanlarda yüksek bulunmuştur $(p=0,024)$. Vaka ve karşılaştırma gruplarında sözel ve fiziksel şiddete mağruz kalanların anksiyete düzeyleri, şiddete mağruz kalmayanlara göre yüksek bulunmuştur (vaka; $p=0,006$, karşılaştırma; $p=0,003$ ).

Sonuç: Acil servis çalışanlarında hafif düzeyde anksiyete ve depresyon izlenmektedir. Ancak sözel veya fiziksel şiddet ve çalışma şartlarının zorluğunun anksiyete ve depresyon üzerinde en etkili faktörler olduğu gözlemlenmiştir. Acil servis çalışanları için çalışma şartlarının düzenlenmesi ve sözel ve fiziki şiddet için önleyici çalışmaların planlanması gerekmektedir.

Anahtar Kelimeler: Acil, anksiyete, depresyon

working at emergency department which could affect job satisfaction, carrying quality (2). Stress shows up as a result of the interactions between individual and environment. Although stress is considered a natural 
survival response, for survival, long term stress can cause physical and psychological problems (3). Long term stress is responsible for the musculoskeletal symptoms, exhaustion and burnout syndrome with the psychiatric symptoms like drug abuse, depression and anxiety disorders $(3,4)$. These symptoms can result in apathy, irritability, angriness, unconcern, or absenteeism (5).

It is reported that depression occurrence frequency is higher among medical staff than the other part of the society. Also, a study which is conducted with 1200 medical staff showed that $6.5 \%$ of women and $9.4 \%$ of men participant has depression (6). Another study which is conducted in emergency department reveals that nearly half of nurses has burnout syndrome (7).

Defining the psychological problems and risk factors among the medical staff could be helpful to upgrade working conditions in the future. The purpose of this study is defining the anxiety, depression levels and related factors of emergency medicine professionals.

\section{METHODS}

This study is conducted in Eskişehir State Hospital and Eskişehir Yunus Emre State Hospital which have nearly 300.000 patient applications per year in the emergency department in Turkey. 75 medical professionals (nurse, emergency medicine technician and paramedic) who are already working at the emergency department and as a comparison group 75 medical professionals who are working at other departments of the hospital for one year but have worked at emergency department before, have participated in this study. Other criteria for participation are determined as; not using drug actively, not having alcohol addiction, not having systemic metabolic disorder, not having a neurological disease which affects central neurological system and not using a medicine which has an effect on personal psychology. An official permission is given by the ethic committee of
Eskisehir State Hospital with the decision number 22205031-051/24 for this study.

The questionnaire form which was prepared for this study was containing the purpose of the study, the information about the study was having a basis on voluntariness, and a consent form which guaranteed the privacy. The names of the participants were not asked.

Data collection has been performed via questionnaire form which has 3 sections: (1) demographic information (age, marital status, economical status, physical working conditions and working hours, being subjected to physical or verbal violence and smoking) (2) Beck Anxiety Inventory (BAI), (3) Beck Depression Inventory (BDI).

Beck Anxiety Inventory was invented by Aaron T. Beck in 1988. BDI is a self-evaluation scale in 21 subjects. The subjective, somatic and panic related symptoms of anxiety are described in the subjects of BAI. Each subject has 4 options which have a value between 0-3. In the sum of these 21 subjects the scale gives a value between 0-63. Higher total values show higher anxiety symptoms. The results from the scale can be evaluated as: 0-7 minimal, 8-15 mild, 16-25 moderate and 26-63 severe anxious symptoms (8).

Beck Depression Inventory was invented by Aaron T. Beck in 1961. BDI is a self-evaluation scale which measures depressive symptoms and shows the characteristic approaches in 21 subjects. Patients answer the questions or subjects by marking on the scale. Each subject has a value between 0-3 increasingly and the total point is calculated by summing all the values. The total value differs between $0-63$. The result from the scale can be evaluated as: 0 9 minimal, 10-16 mild, 17-29 moderate and 30-63 severe depression symptoms (9). 


\section{Statistical Analysis}

The data which is collected in the survey has been analyzed by using SPSS (Statistical Package for Social Sciences) for Windows 21.0 program. In the process of data analysis the descriptive statistical methods (digit, percent, average, and standard deviation) have been used. Mann-Whitney U, T-Test and Kruskal Wallis Test have been used for quantitative data. The data has been estimated in the 95\% confidence interval and 5\% significancy level.

\section{RESULTS}

In this study 75 medical professionals have been estimated and 75 medical professionals have been participated as comparison group. Mean age of actively working group was $34.74 \pm 7.85$ years and control group was $34.28 \pm 7.62$ years. Demographic features of the participants are shown in Table 1.

The average anxiety value of actively working group has been determined as $13.20 \pm 10.91$, the average anxiety value of comparison group has been calculated as $12.08 \pm 10.01$. The average of the depression value of working group has been $10.30 \pm 8.87$ and the average of the depression value of comparison group has been $9.18 \pm 8.14$. In the actively working group the anxiety levels have been detected as follows: $30(40 \%)$ of the participants minimal, 21 (28\%) of the participants mild, 12 (16\%) participants moderate and 12 (16\%) participants showed severe anxiety symptoms. Additionally, in this actively working group depression levels have been determined as follows: 41 (54.66\%) of the participants minimal, 20 (26.64\%) of the participants mild, $12(16 \%)$ of the participants moderate and $2(2.7 \%)$ of the participants showed severe depression symptoms. In the comparison group the anxiety levels have been detected as follows: 30 (40\%) of the participants minimal, $23(30.7 \%)$ of the participants mild, 12 (16\%) participants moderate and $10(13.3 \%)$ of participants showed severe anxiety symptoms. In addition, in this comparison group depression levels have been determined as follows: 46 (61.3) of the participants minimal, 18 (24\%) of the participants mild, $9(12 \%)$ of the participants moderate and $2(2.7 \%)$ of the participants showed severe depression symptoms.

A significant relation between the age and anxiety or depression has not been detected in the actively working group and the comparison group $(p>0.05)$.

In the perspective of working conditions (physical conditions or working hours), it is detected that the better working conditions decreases the depression levels in the actively working group. The depression level of participants who are dissatisfied with the working conditions has been higher than the depression level of the participants who are satisfied with the working conditions $(p<0.05)$. The average value of depression level of the participants dissatisfied with the working conditions has been calculated as $13.690 \pm 10.029$, the average value of the participant partially satisfied with the working conditions has been determined as $8.457 \pm 7.532$ and the average value of satisfied participants has been $7.273 \pm 7.268$. In the actively working group, the average value of anxiety levels of the participants who have been dissatisfied, partially satisfied and satisfied with the working conditions has been calculated as $15.724 \pm 11.029$, $12.000 \pm 10.499, \quad 10.364 \pm 11.587 \quad$ ( $p>0.05)$ respectively. In the comparison group a significant difference has not been detected.

In the actively working group, anxiety level of participants who have been subjected to verbal or physical violence has been determined higher than the other participants and this has been evaluated as statistically significant $(p<0,05)$. Likewise, in the comparison group anxiety level of participants who have been subjected to verbal or physical violence has been determined higher $(p<0.05)$. In both study groups depression levels have not been differed. 
Table 2. Demographic Features of the Participants

\begin{tabular}{|c|c|c|c|c|}
\hline & \multicolumn{2}{|c|}{ Working group /incident } & \multicolumn{2}{|c|}{ Control } \\
\hline & $\mathbf{n}$ & $\%$ & $\mathbf{n}$ & $\%$ \\
\hline $\begin{array}{l}\text { Gender } \\
\text { Male } \\
\text { Female }\end{array}$ & $\begin{array}{l}20 \\
55\end{array}$ & $\begin{array}{l}26.6 \\
73.4\end{array}$ & $\begin{array}{l}18 \\
57\end{array}$ & $\begin{array}{l}24 \\
76\end{array}$ \\
\hline $\begin{array}{l}\text { Occupation } \\
\text { Nurse } \\
\text { Medical assistant } \\
\text { Emergency medicine technician/paramedic } \\
\text { Other }\end{array}$ & $\begin{array}{c}29 \\
14 \\
9 \\
23\end{array}$ & $\begin{array}{l}38.7 \\
18.7 \\
12.0 \\
30.7\end{array}$ & $\begin{array}{l}33 \\
12 \\
13 \\
17\end{array}$ & $\begin{array}{l}44.0 \\
16.0 \\
17.3 \\
22.7\end{array}$ \\
\hline $\begin{array}{l}\text { Marrital Status } \\
\text { Single } \\
\text { Married } \\
\text { Divorced/Lost Wife or Husband }\end{array}$ & $\begin{array}{c}21 \\
47 \\
7\end{array}$ & $\begin{array}{c}28.0 \\
62.7 \\
9.3\end{array}$ & $\begin{array}{c}18 \\
50 \\
7\end{array}$ & $\begin{array}{r}24.0 \\
66.7 \\
9.3\end{array}$ \\
\hline $\begin{array}{l}\text { Financial income satisfaction } \\
\text { Yes } \\
\text { No }\end{array}$ & $\begin{array}{l}35 \\
40\end{array}$ & $\begin{array}{l}46.7 \\
53.3\end{array}$ & $\begin{array}{l}38 \\
37\end{array}$ & $\begin{array}{l}50.7 \\
49.3\end{array}$ \\
\hline $\begin{array}{l}\text { Working conditions satisfaction } \\
\text { Yes } \\
\text { No } \\
\text { Partially }\end{array}$ & $\begin{array}{l}11 \\
29 \\
35\end{array}$ & $\begin{array}{l}14.7 \\
38.7 \\
46.7\end{array}$ & $\begin{array}{l}15 \\
26 \\
34\end{array}$ & $\begin{array}{l}20.0 \\
34.7 \\
45.3\end{array}$ \\
\hline $\begin{array}{l}\text { Being subjected to verbal or physical } \\
\text { violence } \\
\text { Yes } \\
\text { No }\end{array}$ & $\begin{array}{l}65 \\
10\end{array}$ & $\begin{array}{l}86.7 \\
13.3\end{array}$ & $\begin{array}{c}66 \\
9\end{array}$ & $\begin{array}{l}88.0 \\
12.0\end{array}$ \\
\hline $\begin{array}{l}\text { Smoking } \\
\text { Yes } \\
\text { No }\end{array}$ & $\begin{array}{l}31 \\
44\end{array}$ & $\begin{array}{l}41.3 \\
58.7\end{array}$ & $\begin{array}{l}31 \\
44\end{array}$ & $\begin{array}{l}41.3 \\
58.7\end{array}$ \\
\hline
\end{tabular}

The data has been revealed that smoking has not significantly affected anxiety and depression levels in the working group and the comparison group ( $p>0.05$ ).

\section{DISCUSSION}

This study shows that emergency medicine professionals have mild level depression. According to another study which is conducted in Greece also declared this fact similarly (3).

Mild anxiety generally has an effective role on being energized, motivated and handling stress. For this reason mild anxiety in emergency department staff can be assumed as productive motivation. However, in the different levels of anxiety this would cause dispiritedness and severe level of anxiety would result in serious concentration disorders, distractibility and effective problem solving disability or panic reactions
(3). It is known that mental disorders and psychological problems have a frequent occurrence among medical staff (10-12). In the content of this study further investigations should be made to show the relation between working factors and the existing anxiety and depression symptoms.

Physical working conditions and working hours seriously affect medical professionals. It is known that working with a shift system has negative effects on physiology, psychology and social life (13).

It is expected that anxiety levels of medical staff is high because of long working hours and physically and socially inappropriate working conditions and irregular sleeping pattern $(14,15)$. Another study which is performed with 1195 medical staff showed that anxiety and depression has a higher occurrence frequency among people who is working within shifting system 
than the people who is working with regular system (16). It is indicated that nurses who is working with intense work pressure and work overload has long term stress which results in burnout syndrome (17). It is also declared that enough amounts of modern tools and physical hardware which makes the work easier have a positive impact on the burnout levels of nurses (18). In our study, although the depression level of emergency department staff is high, it is not detected in comparison group. It can be thought that the reason of this is the physical incompetency of the public hospitals is more than the other clinics in Turkey.

One of the factors in hospital success is patient satisfaction. This issue is directly related to the interest, guidance, knowledge and speed of service of the medical professionals (19). In a study about patient satisfaction in the Emergency Department, it is stated that adjusting patient care areas and medical staff situation will reduce patient dissatisfaction (20).

We think that the arrangement of physical conditions and working hours will have a positive effect on both the medical professionals and the patients.

It is shown that violence causes angriness, despair, fear, burnout syndrome, loss of confidence and selfrecrimination in medical staff $(21,22)$. Violence has psychological impacts on employees. A study showed that $45 \%$ of the nurses have stress, $47 \%$ of them have inefficiency and $10 \%$ of them are considering leaving the job after violence (23).

It is found that violence is directly related with depression and burnout syndrome in emergency department professionals (24). Our study has similar results with literature and shows that emergency department staff should be supported after violence. We consider that causes and effects of violence should be evaluated and the motivation of emergency department staff should be increased.

It is indicated that smoking increases the risk of anxiety and depression (25-27). But in our study a relation between smoking and anxiety or depression is not detected. The reason could be assumed that the amount of participants is not enough in our study.

\section{CONCLUSION}

During the evaluation of the anxiety and depression levels of emergency department staff it is recorded that verbal and physical violence and working conditions (physical conditions and working hours) has a big impact. Additionally, these factors do not affect the anxiety and depression levels of professionals who are not working at emergency departments. It is required that architectural arrangements should be applied and preventive studies to avoid the violence events should be planned in order to improve the psychological situation of emergency medicine professionals. Also, in order to understand the mental status of emergency medicine professionals more comprehensive studies should be performed.

Informed Consent: Informed consent was obtained from patients who participated in this study.

Conflict of Interest: The authors declare that they have no conflict of interest.

Financial Disclosure: This research did not receive any specific grant from funding agencies in the public, commercial, or not-for-profit sectors

\section{REFERENCES}

1. Arora M, Asha S, Chinnappa J, Diwan AD. Review article: burnout in emergency medicine physicians. Emerg Med Australas. 2013 Dec;25(6):491-5.

2. Fernandez-Parsons R, Rodriguez L, Goyal D. Moral distress in emergency nurses. J Emerg Nurs. 2013 Nov;39(6):547-52.

3. Stathopoulou H, Karanikola MN, Panagiotopoulou F, Papathanassoglou ED. Anxiety levels and related symptoms in emergency nursing personnel in Greece. J Emerg Nurs. 2011 Jul;37(4):314-20.

4. Mealer ML, Shelton A, Berg B, Rothbaum B, Moss M. Increased prevalence of post-traumatic stress disorder symptoms in critical care nurses. Am J Respir Crit Care Med. 2007 Apr 1;175(7):6937.

5. Kawano Y. Association of job-related stress factors with psychological and somatic symptoms among Japanese hospital 
nurses: effect of departmental environment in acute care hospitals. J Occup Health. 2008;50(1):79-85.

6. Martin F, Poyen D, Bouderlique E, et al. Depression and Burnout in Hospital Health Care Professionals. Int $\mathrm{J}$ Occup Environ Health. $1997 \mathrm{Jul} ; 3(3): 204-209$.

7. Yıldırım A, Hacıhasanoğlu R. Quality of Life and Effective Variables Among Health Care Professionals. J Psy Nurs. 2011;2(2):61-68.

8. Beck AT, Epstein N, Brown G, Steer RA. An inventory for measuring clinical anxiety: psychometric properties. J Consult Clin Psychol. 1988 Dec;56(6):893-7.

9. Beck AT, Ward $\mathrm{CH}$, Mehdelson M, Mock J, Erbaugh J. An inventory for measuring depression. Arch Gen Psychiatry. 1961 Jun;4:561-71.

10. Yang MS, Pan SM, Yang MJ. Job strain and minor psychiatric morbidity among hospital nurses in southern Taiwan. Psychiatry Clin Neurosci. 2004 Dec;58(6):636-41.

11. Fagin L, Brown D, Bartlett H, Leary J, Carson J. The Claybury Community Psychiatric Nurse Stress Study: is it more stressful to work in hospital or the community? J Adv Nurs. 1995 Aug;22(2):347-58.

12. Burbeck R, Coomber S, Robinson SM, Todd C. Occupational stress in consultants in accident and emergency medicine: a national survey of levels of stress at work. Emerg Med J. 2002 May;19(3):234-8.

13. Tamagawa R, Lobb B, Booth R. Tolerance of shift work. Appl Ergon. 2007 Sep;38(5):635-42.

14. Akerstedt T. Shift work and disturbed sleep/wakefulness. Occup Med (Lond). 2003 Mar;53(2):89-94.

15. Keller SM. Effects of extended work shifts and shift work on patient safety, productivity, and employee health. AAOHN J. 2009 Dec;57(12):497-502

16. Ardekani ZZ, Kakooei H, Ayattollahi SM, Choobineh A, Seraji GN. Prevalence of mental disorders among shift work hospital nurses in Shiraz, Iran. Pak J Biol Sci. 2008 Jun 15;11(12):16059.
17. Garrett DK, McDaniel AM. A new look at nurse burnout: the effects of environmental uncertainty and social climate. J Nurs Adm. 2001 Feb;31(2):91-6.

18. Kebapçı A, Akyolcu N. The effects of the work environment on nurse burnout in emergency department. Turk J Emerg Med. 2011;11(2):59-67.

19. Al B, Yıldırım C, Togun i, et al. Factors that affect patient satisfaction in emergency department. JAEM. 2009;8(1):39-44.

20. Ayyıldız F, Başpınar İ, Ayyıldız A, et al. Satisfaction Levels of Patients Who Were Followed In Emergency Department And Evaluation Of The Factors That Impact The Outcome. Eskisehir Med J. 2021;2(1):1-5.

21. Fernandes CM, Bouthillette F, Raboud JM, et al. Violence in the emergency department: a survey of health care workers. CMAJ. 1999 Nov 16;161(10):1245-8.

22. Erickson L, Williams-Evans SA. Attitudes of emergency nurses regarding patient assaults. J Emerg Nurs. 2000 Jun;26(3):210-5.

23. Şahin B, Gaygısız S, Balcı FM, et al. Violence against allied healthcare personnel in an emergency department. Turk J Emerg Med. 2011;11(3):110-4.

24. Roldan GM, Salazar IC, Garrido L, et al. Violence at work and it relationship with burnout, depression and anxiety in healthcare professionals of the emergency departments. Health. 2013;5(2):193-9.

25. Klungsøyr O, Nygård JF, Sørensen T, Sandanger I. Cigarette smoking and incidence of first depressive episode: an 11-year, population-based follow-up study. Am J Epidemiol. 2006 Mar 1;163(5):421-32.

26. Morissette SB, Tull MT, Gulliver SB, Kamholz BW, Zimering RT. Anxiety, anxiety disorders, tobacco use, and nicotine: a critical review of interrelationships. Psychol Bull. 2007 Mar;133(2):24572.

27. Mykletun A, Overland S, Aarø LE, Liabø HM, Stewart R. Smoking in relation to anxiety and depression: evidence from a large population survey: the HUNT study. Eur Psychiatry. 2008 Mar;23(2):77-84. 